\title{
Eliciting plant defense on anthracnose disease in chili (Capsicum annuum Linn.) by sodium nitroprusside solution
}

\author{
Vo Thi Thuong', Pongphen Jitareerat ${ }^{1,2, *}$, Apiradee Uthairatanakij ${ }^{1,2}$ \\ ${ }^{1}$ Postharvest Technology Division, School of Bioresources and Technology, King Mongkut's University of Technology Thonburi, Bangkok \\ 10150, Thailand \\ ${ }^{2}$ Postharvest Technology Innovation Center, Commission of Higher Education, Bangkok 10400, Thailand
}

Email address:

thuong.vo.kmutt@gmail.com (Vo T. T.), pongphen.jit@kmutt.ac.th (P. Jitareerat), apiradee.uth@kmutt.ac.th (A. Uthairatanakij)

\section{To cite this article:}

Vo Thi Thuong, Pongphen Jitareerat, Apiradee Uthairatanakij. Eliciting Plant Defense on Anthracnose Disease in Chili (Capsicum annuum Linn.) by Sodium Nitroprusside Solution. Journal of Food and Nutrition Sciences. Special Issue: Food Processing and Food Quality.

Vol. 3, No. 1-2, 2015, pp. 20-27. doi: 10.11648/j.jfns.s.2015030102.14

\begin{abstract}
The study on the induction of plant defense against to anthracnose disease of chili by sodium nitroprusside solution was investigated during pre- and post-harvest. Pre-harvest treatment was conducted by spraying the chili plants with sodium nitroprusside (SNP, nitric oxide donor) solution at 0 (control), 0.05 and $0.1 \mathrm{mM}$ every 3 days for 9 times before inoculating with the spore suspension of Colletotrichum gloeosporioides (the causal agent of anthracnose disease) and then sprayed with SNP again 1 time after inoculating. The results revealed that $0.1 \mathrm{mM}$ SNP was the best concentration to suppress anthracnose disease by reducing disease incidence and disease index on chili leaves, and showing the lowest loss of yield caused by anthracnose disease. This founding also showed that either pathogenic inoculation or SNP treatment had ability to induce the activities of peroxidase (POD) and phenylalanine ammonia lyase (PAL) of chili leaves, particularly the chili plant inoculated with pathogenic fungi followed by treated with $0.1 \mathrm{mM}$ SNP showed the highest POD and PAL activities. Postharvest treatment was done by inoculating the mature chilli fruit with C. capcisi for $4 \mathrm{~h}$ and followed by dipping in 0 (control) and $4 \mathrm{mM}$ SNP. All fruit samples were kept at $13^{\circ} \mathrm{C}$ for 15 days. The results showed that chili fruit dipped with 4 mM SNP reduced disease incidence, disease index, delayed weight loss, respiration rate, ethylene production, and also maintained the changes of fruit color $(\Delta \mathrm{E})$ better than non-treated fruit (control). The activities of chitinase (CHI) and $\beta$-1,3-glucanase )GLU( in chili fruit were induced by SNP with the highest peak on day 6 of storage but they were not significant different with the control fruit. These results indicated that SNP might potential leading to the reduction of anthracnose disease in chili by eliciting plant defense related enzymes in both pre- and post-harvest periods.
\end{abstract}

Keywords: Chitinase, $\beta-1,3-$ Glucanase, Peroxidase, Phenylalanine Ammonia Lyase, Nitric Oxide

\section{Introduction}

Chili (Capsicum annuum Linn.) is a major fruit crop of the world, a member of Solanaceae or nightshades family. It have beneficial in term of medicinal and health. Because of the rising demand the fresh chili and the chief spice composition in cuisine. The extending the shelf-life of harvested chili fruit with maintain high quality is great importance. However, anthracnose disease caused by Colletotrichum spp. including C. gloeosporioides Penz., C. capsici Syd., C. acutatum Simmonds., and C. coccodes Wallr. [24, 10, 11, 21], which is a main disease and starts deteriorating at both pre- and post-harvest in chili fruit.
Anthracnose disease is a key to losing its marketable and quality of chili fruit [15]. Thus, prolonging postharvest shelf-life by preventing pathogenic invasion would benefit for the consumer as well as chili industry. Although various methods including the cultural practices, chemical practices and biological practices, have been used to manage anthracnose disease in chili [3]. Disease infection or other stress conditions have been indicated to eliciting multiple plant resistances involving structural (cuticle, stomata, and cell wall protein), biochemical defense (the accumulation of hydrogen peroxide, phytoalexins, phenols), and other 
pathogenesis-related proteins (chitinase and $\beta$-1,3-glucanse) $[27,31]$. For example, mycelium extracts of Phytophthora spp. could induce protective mechanism related in suppressing pathogen development in Nicotiana species [32].

Nitric oxide (NO) is free radical gas which is an important signaling molecule physiological processes and defense responses in plant [7]. Pre-harvest treatment application of NO has been reported to response to the Diaporthe phaseolorum by accumulating phytoalexin in soybean cotyledons [18] and in tobacco leaves [7]. After pathogen invasion, NO was accumulated and activates expression of phenylalanine ammonia-lyase (PAL) and a series of resistance-related genes [30, 7]. In addition, postharvest exogenous application of NO induced defense enzymes including PAL, chitinase $(\mathrm{CHI}), \beta$-1,3-glucanase (GLU) and promoted expression of pathogenesis related protein 1 (PR protein 1) in tomatoes fruit [34]. NO not only regulate plant resistance through direct regulation of defense enzymes and related genes [7, 25]. NO fumigation also inhibited ethylene biosynthesis in resulting suppressed the content of 1-aminocyclopropane-1-caboxylic acid (ACC) and the activity of ACC synthase (ACS) in banana [6], mangoes [32] and oranges [14].

As the previous research on above, NO have beneficial to induce plant defense responses during pathogen infection, delay ripening and senescence processes, and extend the shelf-life of several produce [7, 35, 34, 32]. Little information reported NO function in activating plant defense in pre- and post-harvested chili. Therefore, the aim of this study was to investigate the effect of NO in eliciting plant defense on anthracnose disease in chili during preand post-harvest period. The changes in physiological parameters of chili fruit with pre-and postharvest NO treatments were also determined.

\section{Materials and Methods}

\subsection{Fungal Isolation and Culture Conditions}

C. gloeosporioides and C. capsici, caused of anthracnose disease, were isolated from natural infected chili fruit by the tissue transplanting method. They were then identified and confirmed an isolated organism as a plant pathogen using Koch's postulation (Agrios, 2005). Each isolated fungus was cultured on potato dextrose agar (PDA) at $27^{\circ} \mathrm{C}$ for 1 week. The conidia were harvested from the media to prepare the spore suspension. Fungal spores were obtained by flooding the surface of the culture with sterile distilled water containing $0.05 \%(\mathrm{v} / \mathrm{v})$ Tween-20. The suspension was adjusted to a concentration of $1 \times 10^{7}$ spore/mL using a hemocytometer.

\subsection{Pre-Harvest Treatment}

Chili seeds were planted in pots under green house. After 60 days growing, plants were sprayed with the solution of 0 (control), 0.05 and $0.1 \mathrm{mM}$ sodium nitroprusside (SNP; nitric oxide donor) (HiMedia Laboratories Pvt. Ltd.) every 3 days for 9 times (totally 27 days). The plants treated with SNP were then inoculated with $20 \mathrm{~mL}$ of $C$. gloeosporioides $\left(10^{7}\right.$ spore $\left./ \mathrm{mL}\right)$. Each inoculated plants were covered with plastic bag for $24 \mathrm{~h}$ to keep high moisture which was the appropriate condition of fungal invasion. All inoculated plants were then sprayed with SNP at the same concentration again 1 time after inoculating. Noninoculated plants were sprayed with water served as the control. Each treatment contained 16 plants which divided into four groups and performed as the four replications. After 1, 15, 48 and $72 \mathrm{~h}$ of inoculation and treatments with SNP, chili leaves were harvested, instantly dipped in liquid nitrogen, and then crushed to a fine powder with mortar and pestle. The powder was stored at $-20^{\circ} \mathrm{C}$ for enzymes analysis. Disease incidence, disease severity and disease index were observed on leaves every 1, 2, 5, 10 and 15 days after treatments. Yield loss caused by anthracnose disease was measured on day 15 of treatments.

\subsection{Postharvest Treatment}

Chili fruit were purchased from the whole sale market, Pathumthani province, and transported to the laboratory of Postharvest Technology Division within $1 \mathrm{~h}$. The fruit were selected for uniform size and color, freedom from disease infects and mechanical damage. Spore suspension of $C$. capsici were inoculated on chili fruit and kept in the closed chamber to maintain high moisture for $4 \mathrm{~h}$. The inoculated fruit were then randomly divided into two lots of 100 fruit each, including four replicates with 20 fruit in each replicate. As our preliminary tests showed, dipping the chili fruit with 1-4 mM SNP solution did not have any negative effect to chili fruit. Therefore, $4 \mathrm{mM}$ SNP solution was selected to use in this experiment. The first lot was dipped with $4 \mathrm{mM}$ SNP solution supplemented with $1 \mu \mathrm{L}$ Tween-20 to reduce surfactant for $5 \mathrm{~min}$. The second lot of fruit was dipped in sterile distilled water served the control. The experiments were implemented at room temperature $\left(23^{\circ} \mathrm{C}\right)$, then stored at $13^{\circ} \mathrm{C}$ and $90-95 \%$ relative humidity for 15 days. Every 3 days, disease incidence, disease severity, disease index, weight loss, firmness, respiration rate and ethylene production were determined. Flesh of fruit samples from 20 fruit of four replicates were cut into small pieces, frozen with liquid nitrogen and kept at $-20^{\circ} \mathrm{C}$ for enzymes analysis.

\subsection{Disease and Yield Loss Measurement}

Disease incidence was expressed as a percentage of leaves or fruit showing anthracnose symptoms. Disease severity was determined on a scale $0-5$, with $0=$ apparently healthy, 1 = slight infection on an individual leaves/fruit, 2 $=25 \%$ of a leaves/fruit infected, $3=50 \%$ of a leaves $/$ fruit infected, $4=75 \%$ of a leaves/fruit infected and $5=100 \%$ of a leaves/fruit infected. Disease index (DI) was measured using the method described by Meng et al. (2008), was 
calculated as $\mathrm{DI}=\sum(\mathrm{df}) / \mathrm{ND}$, where $\mathrm{d}=$ the degree of rot severity assessed on the leaves/fruit, $\mathrm{f}=$ respective quantity of leaves/fruit, $\mathrm{N}=$ the total number of leaves/fruit examined and $\mathrm{D}=$ the highest degree of disease severity occurring on the scale. The percentage of yield loss cause by anthracnose disease was calculated as: (the weight of anthracnose fruit (g)/total yield of fruit).

\subsection{Quality Assessment}

Weight loss of chili fruit was determined by weighing each treatment containing 20 fruit with the balance (Ohaus Corporation, USA). The data were calculated as the percentage of weight loss. The changes skin color of fruit parameters including $\mathrm{a}^{*}$ and $\mathrm{L}^{*}$ were measured using a Minolta Colorimeter (Model RC 300). Pericarp firmness of fruit was measured with a Texture Analyzer (TA-XT2, Stable Micro-system, England) equipped with a $3 \mathrm{~mm}$ diameter probe. The measurements were taken in the equatorial fruit zone to a depth of $5 \mathrm{~mm}$ at a rate of $5 \mathrm{~mm}$ per min and force was expressed in Newtons $(\mathrm{N})$.

\subsection{Measurement of Respiration Rate and Ethylene Production}

Respiration rate of the fruit (five fruit randomly selected from each replicate) was determined using gas chromatograph GC-8A (Shimadzu, Japan) fitted with a 4 min long stainless steel column (Porapack N column) and Thermal Conductivity Detector (TCD). Helium was used as the carrier gas at a flow rate of $30 \mathrm{~mL} / \mathrm{min}$ and column temperature was maintained at $50^{\circ} \mathrm{C}$. The fruit were placed in $1200 \mathrm{~mL}$ plastic box for $1 \mathrm{~h}$ at $13^{\circ} \mathrm{C}$, then $1 \mathrm{~mL}$ gas sample injected into a gas chromatograph. Respiration rate was expressed as $\mathrm{mg} \mathrm{CO} / \mathrm{kg}$.h. Ethylene production was measured by a GC-14B (Shimadzu, Japan) installed with a Flame Ionization Detector (FID) and a $2 \mathrm{~m} \mathrm{x} 4 \mathrm{~mm}$ stainless steel column packed with 80-100 mesh Porapack Q. The carrier gas was nitrogen with a flow rate of $35 \mathrm{~mL} / \mathrm{min}$ and the temperature of the injector and column was maintained at $120^{\circ} \mathrm{C}$ and $80^{\circ} \mathrm{C}$, respectively. Ethylene production was expressed as $\mathrm{nL} \mathrm{C}_{2} \mathrm{H}_{4} / \mathrm{kg} \cdot \mathrm{h}[12]$.

\subsection{Plant Defense Enzymes}

POD activity was assayed as previously described by Wang (1982) with some modifications; $0.5 \mathrm{~g}$ of frozen samples was homogenized in $12 \mathrm{~mL}$ of ice-cold extraction $0.1 \mathrm{M}$ phosphate buffer $(\mathrm{pH}$ 6.1) containing 0.9 g polyvinyl-pyrolidone (PPVP) and $3 \mathrm{~g}$ of sodium ascorbate. The homogenate was centrifuged at $12,000 \times \mathrm{g}$ for $10 \mathrm{~min}$ at $4^{\circ} \mathrm{C}$ and the supernatant was used for measurement of POD enzyme activities. A $4.8 \mathrm{~mL}$ sample of assay mixture containing $2 \mathrm{~mL}$ of $4 \mathrm{mM}$ guaiacol, $2.0 \mathrm{~mL}$ of $3 \mathrm{mM} \mathrm{H}_{2} \mathrm{O}_{2}$ and $0.8 \mathrm{mM}$ the crude leaf extract were used. The reaction was allowed to precede for 5 min with optical density (OD) measurements taken every $60 \mathrm{~s}$, beginning $1 \mathrm{~min}$ after the crude leaf extract was added to the substrate [29]. POD enzyme activity was expressed as $\mathrm{OD}_{470} / \mathrm{min} / \mathrm{mg}$ protein.

PAL activity was extracted in $12 \mathrm{~mL}$ of ice-cold extraction $0.2 \mathrm{M}$ sodium borate buffer $(\mathrm{pH} 8.8)$ containing 6 g PPVP, $5 \mathrm{mM} \beta$-mercapto-ethanol, and EDTA. The homogenate was centrifuged at $4{ }^{\circ} \mathrm{C}$ for $25 \mathrm{~min}$ at $14,000 \times$ $\mathrm{g}$ and the supernatant was collected for enzyme assays. PAL was assayed according to Zucker [37] with some modifications by incubating $0.5 \mathrm{~mL}$ of crude extract with $2.0 \mathrm{~mL}$ of $0.1 \mathrm{M}$ borated buffer containing $3 \mathrm{mM} \mathrm{L}$ phenylalanine for $1 \mathrm{~h}$ at $37^{\circ} \mathrm{C}$. PAL activity was expressed as Unit/mg protein.

Chitinase (CHI) and $\beta-1,3$ - glucanase (GLU) assay were conducted by homogenized $5 \mathrm{~g}$ of chili flesh in $0.5 \mathrm{M}$ acetate buffer $(\mathrm{pH} 5.2)$ containing $3 \mathrm{~mL}$ of $15 \mathrm{mM}$ mercapto-ethanol. The homogenate was centrifuged at $16,000 \times \mathrm{g}$ for $20 \mathrm{~min}$ at $4^{\circ} \mathrm{C}$ and the supernatant were collected as a crude enzyme extract. CHI activity was measured as described as in [9] with some modifications. An aliquot $(1 \mathrm{~mL})$ of crude extract was mixed with $0.2 \mathrm{~g}$ colloidal chitin (Sigma) and $2 \mathrm{~mL}$ of $0.1 \mathrm{M}$ citrate buffer (pH 6.0), then incubated at $37^{\circ} \mathrm{C}$ for $1 \mathrm{~h}$. The sample was added with $0.5 \mathrm{~mL} 3,5$-dinitrosalicylic acid (DNS solution) and boiled for $15 \mathrm{~min}$. The reaction was stopped by dipping in ice-cold water. After cooling, the mixture was diluted with $5 \mathrm{~mL}$ distil water and then absorbance was measured at $570 \mathrm{~nm}$. CHI activity was expressed as unit $/ \mathrm{mg}$ protein, where one unit is defined as $\mu \mathrm{g} / \mathrm{mL} \mathrm{N}$ acetylglucoeamine released per hour under these assay conditions. GLU activity was determined with laminarin (Sigma) as the substrate according to as in [20] with some modifications. Crude extract $(0.3 \mathrm{~mL})$ was mixed $1.2 \mathrm{~mL}$ of $1.5 \mathrm{mg} / \mathrm{mL}$ laminarin, and the mixed was incubated at $37^{\circ} \mathrm{C}$ for $20 \mathrm{~min}$. The reaction was stopped by boiling for $5 \mathrm{~min}$ and centrifuged at $2,000 \times \mathrm{g}$ for $5 \mathrm{~min}$ at $37^{\circ} \mathrm{C}$. Then, the mixture of $1 \mathrm{~mL}$ crude extract and $1 \mathrm{~mL}$ Somogyi's reagent was boiled for $20 \mathrm{~min}$. After cooling at $10-15^{\circ} \mathrm{C}, 1 \mathrm{~mL}$ Nelson's reagent was added and the mixture was incubated at $37^{\circ} \mathrm{C}$ for $15 \mathrm{~min}$. Then, $2 \mathrm{~mL}$ distil water was added and absorbance was measured at $520 \mathrm{~nm}$. GLU activity was assayed as the mount of the reducing glucose released from laminarin by using glucose as the standard. Unit of GLU activity was express as unit $/ \mathrm{mg}$ protein, where one unit is defined as $\mu \mathrm{g} / \mathrm{mL}$ glucose produced from laminarin per hour under these assay conditions. Total protein contents in the enzyme extracts was determined according to as in [5], using bovine serum albumin (BSA) as a standard.

\subsection{Statistical Analysis}

Each experiment was repeated three time and the data were performed using a completely randomized design. The data were analyzed by t-test for SNP treatment and control fruit of the same day, comparing treatments at $p \leq 0.05$ was considered statistically significant. 


\section{Results}

\subsection{Effect of Pre-Harvest Treatment with SNP on Anthracnose Disease and Plant Defense Enzymes in Chili}
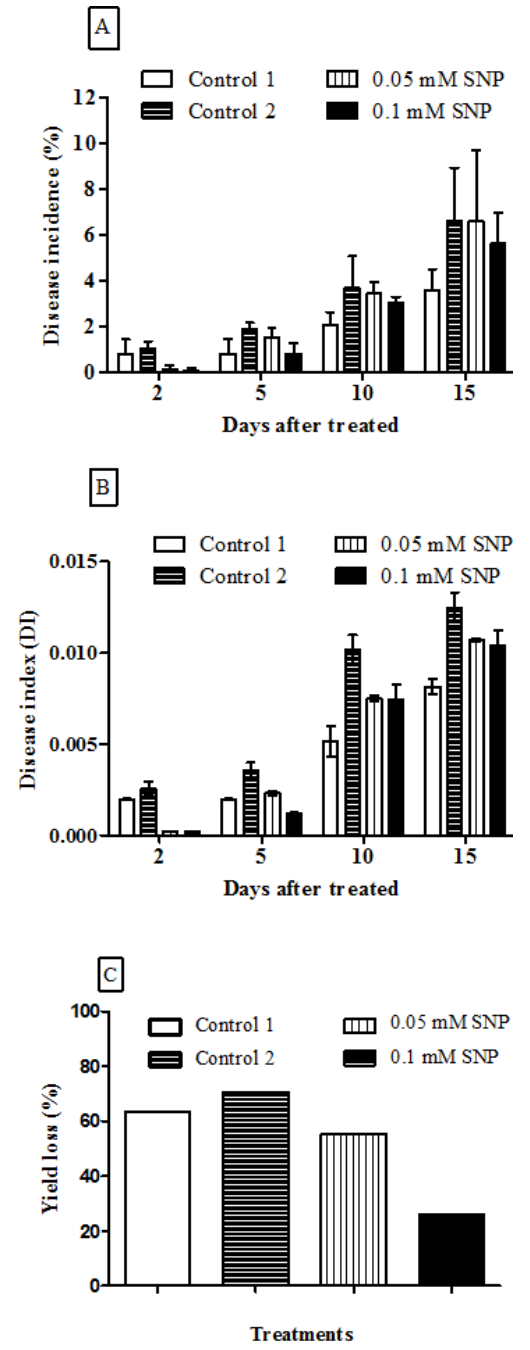

Figure 1. Effect of pre-harvest treatment with SNP on anthracnose disease development in chili plant: (A) Disease incidence, (B) Disease index, and (C) Yield loss. Chili plant were inoculated with Colletotrichum gloeosporioides and sprayed with 0 (control 2), 0.05 and $0.1 \mathrm{mM} \mathrm{SNP.} \mathrm{Non-inoculated} \mathrm{plants}$ sprayed with water were served as the control 1. Each treatment is presented as means $\pm S E$ of four replicates.

Chili plants spraying with SNP at 0.05 and $0.1 \mathrm{mM}$ showed the lower disease incidence than the control plants (both chili plants inoculated and sprayed with distilled water (control 2) and chili plants sprayed with distilled water alone (control 1). The highest disease incidence was found in chili plants inoculated and sprayed with distilled water (control 2) on first 10 days whereas, chili plants were non-inoculated and sprayed with distilled water (control 1) expressed lowest disease incidence $(3.56 \%)$. but was not significantly different among treatments (Figure 1A). Disease severity was observed on day 2 and it was not significantly different during treatments (data no shown). Disease index (DI) tended to increase over time in all treatments (Figure 1B). Control 1 plants showed the lowest DI. The plants treated with SNP were significantly $(\mathrm{p} \leq 0.01)$ lower DI than the control 2 plants, especially; chili plants were sprayed with $0.1 \mathrm{mM}$ SNP. Yield loss cause by anthracnose disease shows in Figure 1C. Plants treated with 0.05 and $0.1 \mathrm{mM} \mathrm{SNP}$ had the lowest yield loss, especially, chili plants were sprayed with $0.1 \mathrm{mM}$ SNP. Meanwhile, control 1 plants (non-inoculated) showed lower yield loss than the control 2 plants (inoculated and non-SNP treatment). These results revealed that application of preharvest SNP treatment might have the potential to suppress anthracnose disease development in chili plants.

POD and PAL activities, the enzyme associated with plant defense were investigated in chili leaves. As shown in Figure $2 \mathrm{~A}$, the higher activity of POD enzyme was observed on chili plant which were inoculated and sprayed with SNP $(0.05$ and $0.1 \mathrm{mM}$ ) for $1 \mathrm{~h}$ and they were higher than the either control plants (inoculated/non-inoculated and sprayed with distilled water). A sharp increasing of POD activity was found in all treatments, reached to the highest levels after treated for $15 \mathrm{~h}$ $\left(2.39 \mathrm{OD}_{470} / \mathrm{min} / \mathrm{mg}\right.$ protein), and then decreased in the following hours which was not significant different among treatments. PAL activity of all inoculated chili plants was significant $(p \leq 0.01)$ higher than that of the control 1 (noninoculated). This indicated that fungal infection alone could stimulate the plant defense response. PAL activity in all treatments increased, reached the peak value at $48 \mathrm{~h}$ after inoculating and spraying with SNP, and then gradually decreased until the end of experiment (Figure 2B). Treatment with $0.1 \mathrm{mM}$ SNP was significant highest the activity of PAL throughout $72 \mathrm{~h}$ after treated ( $0.85 \mathrm{Unit} / \mathrm{mg}$ protein).
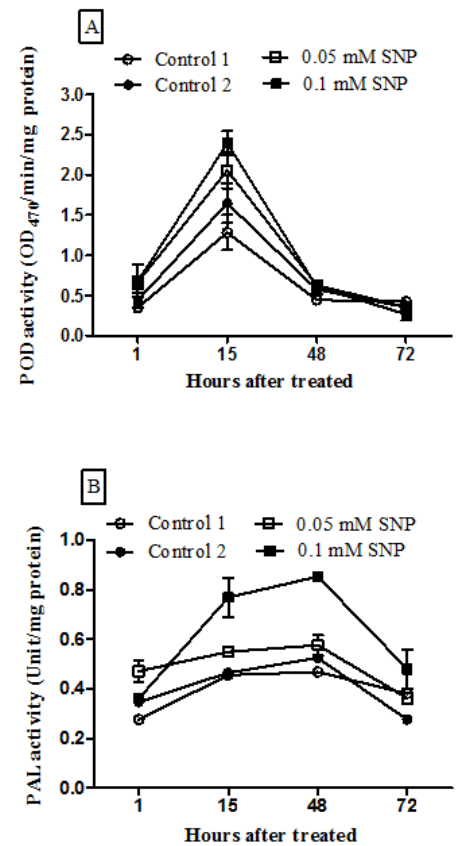

Figure 2. Effect of pre-harvest treatment with SNP on plant defense enzymes in chili leaves: (A) POD activity and (B) PAL activity. Chili plants were inoculated with gloeosporioides and sprayed with 0 (control 2), 0.05 and 0.1 $m M S N P$. Non-inoculated plants sprayed with water were served as the control 1. Each treatment is presented as means $\pm S E$ of four replicates. 


\subsection{Effect of Post-Harvest Treatment with SNP on Anthracnose Disease of Chili Fruit}

Disease incidence was observed on day 6 in the control fruit, meanwhile $4 \mathrm{mM}$ SNP treated fruit extended disease incidence to day 9 of storage at $13^{\circ} \mathrm{C}$ (Figure 3). Dipping of 4 $\mathrm{mM}$ SNP suppressed disease incidence significantly during the first 12 days of storage compared with the control fruit. At the end of storage (day 15), disease incidence was not significantly different between SNP treated fruit and the control fruit. However, SNP treated fruit also significantly $(p \leq 0.01)$ inhibited disease severity on first 9 days of storage. Then, it still increased which was not significantly different from that of the control fruit (data not shown). In contrast, DI of SNP treated fruit was significant lower than the control fruit on day 9-12 of storage time. At last day (15), DI in SNP treatment was 0.75 ; that was similar to the control fruit.

\subsection{Effect of Post-Harvest Treatment with SNP on the Quality of Chili Fruit}

The weight loss increased during the storage time in all
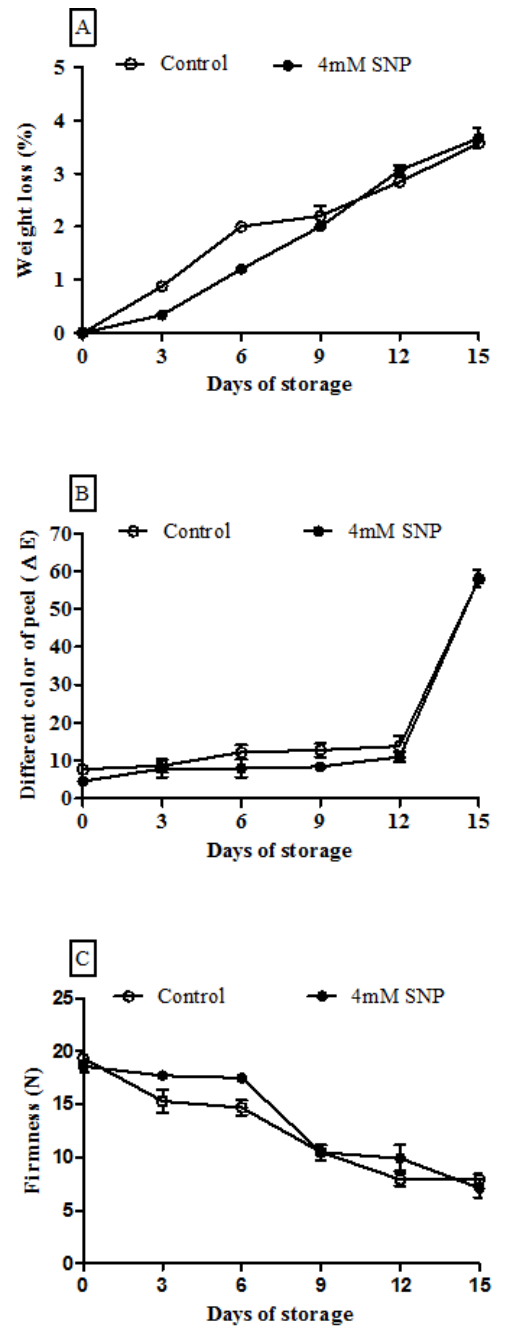

treatments (Figure 4A). SNP treated fruit significantly showed lower in weight loss than the control fruit from the beginning to 9 days of storage. At the end of storage (12 and 15 days), weight loss in non-treated fruit (2.84 and 3.57\%) was not significant different with SNP treated fruit (3.06 and $3.67 \%$, respectively).

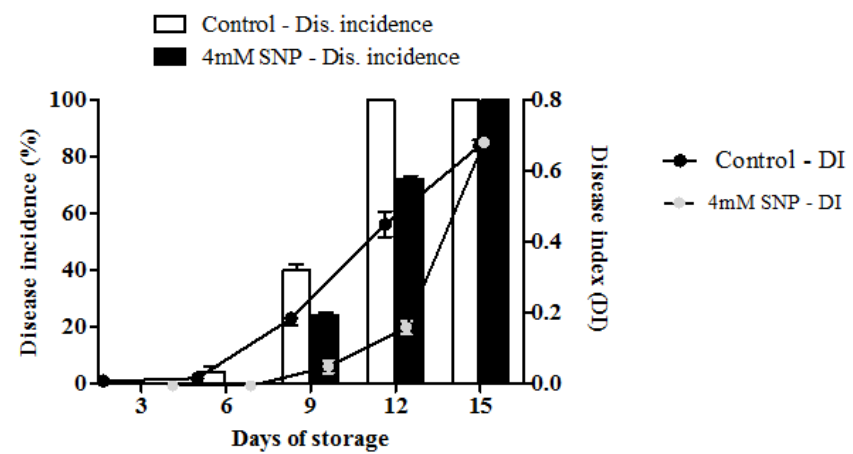

Figure 3. Effect of SNP treatment on disease incidence and disease index of chili fruit. Chili fruit were inoculated with Colletotrichum capsici and dipped with 0 (control) and $4 \mathrm{mM}$ SNP. Each treatment is presented as means \pm SE of four replicates.
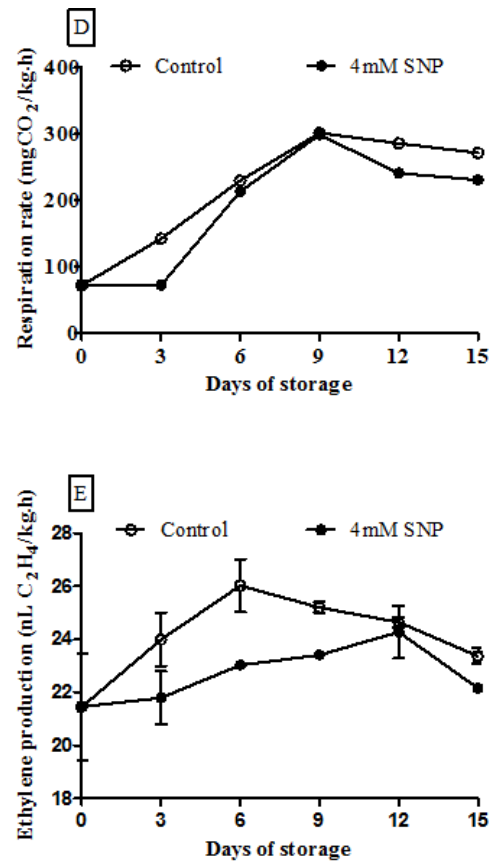

Figure 4. Effect of SNP treatment on physiological changes of chili fruit: (A) Weight loss, (B) Different color of peel (AE), (C) Fruit firmness, (D) Respiration rate, and (E) Ethylene production. Chili fruit were inoculated with Colletotrichum capsici and dipped with 0 (control) and 4 mM SNP. Each treatment is presented as means \pm SE of four replicates. 
There was a significant delayed in the change of the color $(\Delta \mathrm{E})$ of chili fruit after 3 days of SNP treatment in compared to untreated fruit (Figure $4 \mathrm{~B}$ ). Nonetheless, $\mathrm{a}^{*}$ and $\mathrm{L}^{*}$ value still remained higher than that of the control during the storage time (data not shown). On the other hand, the result revealed that $4 \mathrm{mM}$ SNP treatment could help to maintain fruit firmness as shown in Figure 4C. Even through, it was not significant different among treatments during the storage period.

\subsection{Effect of Post-Harvest Treatment with SNP on Respiration Rate and Ethylene Production of Chili Fruit}

Respiration rate of SNP treated fruit was significant lower than the control fruit during storage at $13^{\circ} \mathrm{C}$ (Figure 4D). Respiration rate in the control fruit markedly increased during the first 9 days and reached to $301.75 \mathrm{mg} \mathrm{CO} / \mathrm{kg}$.h. It was higher than that of SNP treated fruit (299.14 mg $\mathrm{CO}_{2} / \mathrm{kg}$.h. After that, the respiration rate of both the control and treated fruit decreased until the end of storage time (12 and 15 days). For ethylene production, SNP treated fruit significantly $(\mathrm{p} \leq 0.01)$ inhibited and delayed the ethylene levels when compared to the control fruit (Figure 4E). The ethylene in the control fruit increased and reached a peak value (26.03 $\left.\eta \mathrm{L} \quad \mathrm{C}_{2} \mathrm{H}_{4} / \mathrm{kg} . \mathrm{h}\right)$ at day 6 of storage, then decreased. The peak value of ethylene production in SNP treated fruit was observed on day 12 among storage period (24.28 $\eta \mathrm{L} \mathrm{C}_{2} \mathrm{H}_{4} / \mathrm{kg} . \mathrm{h}$ ) lower than that of the control fruit.

\subsection{Effect of Post-Harvest Treatment with SNP on Plant Defense Enzymes in Chili Fruit}
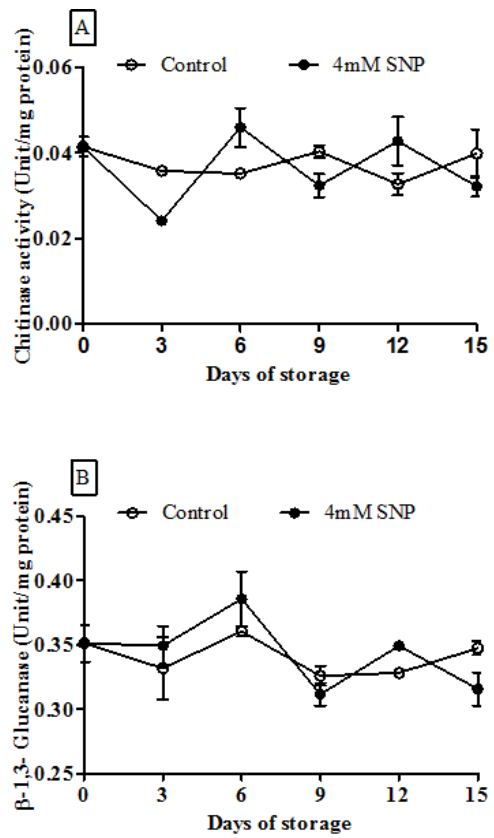

Figure 5. Effect of SNP treatment on plant defense enzymes in chili fruit: $(A)$ Chitinase activity and (B) $\beta$-1,3-glucanase activity. Chili fruit were inoculated with Colletotrichum capsici and dipped with 0 (control) and 4 $m M S N P$. Each treatment is presented as means $\pm S E$ of four replicates.
CHI and GLU activities were determined in chili fruit after treating with SNP compared with non SNP treatment. It was found that $\mathrm{CHI}$ activity in all treatments was low and there was no stable pattern over time during storage at $13^{\circ} \mathrm{C}$ (Figure 5A). The results showed that CHI activity of NSPtreated fruit and the control fruit was about 0.02-0.04 unit/ $\mathrm{mg}$ protein, and its activity was not significantly different among treatments. GLU activity in both treatments markedly increased during first 6 days of storage time (Figure 5B). GLU activity of SNP-treated fruit reached 0.38 unit $/ \mathrm{mg}$ protein which was higher than that of control fruit $(0.36$ unit/mg protein), and then decreased. GLU activity was nonsignificantly different among treatments during storage time.

\section{Discussion}

It has been known that SNP solution released NO after reaction with different reducing agents in plant [4]. In this report, the effects of pre-harvest treatment with SNP solution (NO donors) on anthracnose disease in chili plants were evaluated and expressed as disease incidence, disease severity, disease index, and yield loss. Plant defense enzymes such as POD and PAL activities were also investigated to confirm the result. Treatment with 0.05 and $0.1 \mathrm{mM}$ SNP solution reduced disease development and yield loss by activating the activity of POD and PAL enzymes, especially, chili plant were treated with $0.1 \mathrm{mM}$ SNP solution. The resulted indicated that $\mathrm{NO}$ probably act as an effective promote the mechanism of plant defense. NO is a free radical, it is an important cellular signaling molecule played in various physiological functions and defense responses in [2]. Similarly, NO may participate in suppressing disease invasion in tobacco leafs [7], soybean leafs [22], oranges [14].

The role of the elicitation of plant's defense involved enzymes has been reported by many researchers [28]. POD and PAL are very importance in plant disease resistance. POD is oxidative-lyase enzyme that is known to play a part in promoting a plant's defenses against oxidative stress and pathogens [23]. While PAL is a first key enzyme in the phenylpropanoid pathway that related in the stimulation of lignin and phytoalexins, which are responded to different stimuli like tissue damaging, pathogenic infection [8]. Our data showed that the activities of POD and PAL elevated when chili plants were inoculated and treated with SNP, and their activities reached the peak after treating for 15 and $48 \mathrm{~h}$ respectively. Some research shows that SNP could induce activities of POD and PAL enzymes in Cholrella vugaris [19], tomatoes fruit [13], tomatoes fruit [34] and sweet potato root [30].

Moreover, effects of postharvest SNP treatment on anthracnose disease on chili fruit was investigated during storage at $13^{\circ} \mathrm{C}$. Disease index of $4 \mathrm{mM} \mathrm{SNP}$ treated-fruit was significant lower than in the control fruit on first 12 storage days, which is in agreement with the results as in [14]. They had reported that Glorious oranges fruit were treated with SNP 
could effectively suppress disease incidence when the fruit inoculated with Colletrotichum sp., and inhibit the lesion diameter of fruit during storage period. Similar results have also been reported in tobacco leaves [7]. Pathogenesis-related (PR) proteins are proteins produced in plant that are induced by wounding, low temperature, or pathogen attack. They are induced by the action of signaling molecules salicylic, jasmonic acid or pathogens, and are commonly associated with a systemic acquired resistance (SAR). Chitinase which belong to the PR-3, $-4,-8$ and -11 families, and $\beta-1,3$-glucanase, which belong to the PR-2 family [27], are also induced defense responses. We found that SNP treatment induced $\mathrm{CHI}$ and GLU activities in chili fruit and reached the peak value on day 6 of storage time. Likewise, NO treatment maintained significantly higher levels of $\mathrm{CHI}$ and GLU activities in tobacco leaves [16] and tomatoes fruit [34].

The effect of NO donor was not only involved to enzymes and PR protein participated with disease resistance. This study provided evidence that $4 \mathrm{mM}$ SNP treatment was able to reduce the weight loss by inhibiting an increase in respiration rate of chili fruit during storage time compared to the control fruit. After harvest, fruit is extremely to lose water, which alleviates the freshness and commodity value. It was reported that NO had effect on reducing water loss in oranges [14] and inhibiting the respiration process in mangoes fruit [32]. In addition, SNP-treated fruit was significantly reduce and delayed the peak of ethylene production during storage at $13^{\circ} \mathrm{C}$. Inhibition ethylene production by dipping with $4 \mathrm{mM}$ SNP could delay senescence and ripening processes which retain firmness, color during storage. Similar results have also been reported earlier for strawberries and peaches $[36,35]$.

\section{Conclusions}

Pre-harvest treatment with $0.1 \mathrm{mM}$ SNP solution in chili plant effectively reduced anthracnose disease and yield loss by enhancing POD and PAL activities. Furthermore, SNP treatment also was able to suppress disease development and delay postharvest physiological changes of chili fruit. Thus, our results indicated that SNP solution or NO donors may provide a new simple approach to the reduction of anthracnose disease in chili by eliciting plant defense related enzymes. It is believed that the application of the NO donors is widely used in various agricultural produces is coming.

\section{Acknowledgements}

The first author (Ms. T.T. Vo) would like to thank to King Mongkut's University of Technology Thonburi, Thailand for granting the scholarship and financial support for conducting the experiments.

\section{References}

[1] G.N. Agrios, Plant pathology $\left(5^{\text {th }}\right.$ ed). Elsevier Press Burlington, MA, USA, 922 pp., 2005.
[2] M. Arasimowicz, and J. Floryszak-Wieczorek, "Nitric oxide as a bioactive signaling molecule in plant stress response," J. Plant Science, 172, 876-887, 2007.

[3] J.A. Bailey, and M.J. Jeger, (Eds). Colletotrichum: Biology, pathology and control. Common Wealth Mycological Institute. Wallingford, 388 pp., 1992.

[4] J.N. Bates, M.T. Baker, Jr. Guerra, and D.G. Harrison, "Nitric oxide generation from nitroprusside by vascular tissue: evidence that reduction of the nitroprusside anion cyanide loss are required,” J. Biochemical Pharmacology, vol. 42 (Suppl.1), pp. S157-S165, 1991.

[5] M. Bradford, "A rapid and sensitive method for the quantitation of microgram quantities of protein utilizing the principle of protein dye binding," Analytical Biochemistry, col. 72, pp. 248-254, 1976.

[6] G. Cheng, E. Yang, W. Lu, Y. Jia, Y. Yiang, and X. Duan, "Effect of nitric oxide on ethylene synthesis and softening of banana fruit slice during ripening," J. Agricultural and Food Chemistry, vol. 57, pp. 5799-5804, 2009.

[7] J. Durner, D. Wendehenne, and F.D. Klessig, "Defense gene induction in tobacco by nitric oxide, cyclic GMP and cyclic ADP-ribose,” J. Plant Biology, vol. 95(17), pp. 10328-10333, 1993.

[8] T.L. Graham, and M.Y. Graham, "Signaling in soybean phenylpropanoid response," J. Plant Physiology, vol. 110, pp. 1123-1133, 1996.

[9] R. Gupta, R.K. Saxena, P. Chaturvedi, and J.S. Virdi, "Chitinase production by streptomyces virdificans: its potential in fungal cell walls lysis" J. Appllied Bacteriology, vol. 78, pp. 378-383, 1995.

[10] P.R. Johnston, and D. Jones, "Relationships among Colletotrichum isolates from fruit-rots assessed using rDNA sequences," J. Mycologia, vol. 89(3), pp. 420-430, 1997.

[11] K.D. Kim, B.J. Oh, and J. Yang, "Differential interactions of a Colletotrichum gloeosporioides isolate with green and red pepper fruits," J. Phytoparasitica, vol. 27, pp. 1-10, 1999.

[12] D. Lacan, and J.C. Baccou, “ Changes in lipids and electrolyte leakage during non-netted muskmelon ripening," J. American Society for Horticultural Science, vol. 121, pp. 554-558, 1996

[13] T. Lai, Y. Wang, B. Li, G. Qin, and S. Tian, "Defense responses of tomato fruit to exogenous nitric oxide during postharvest storage," J. Postharvest Biology and Technology, vol. 62,pp. 127-132, 2011.

[14] L. Liu, J. Wang, L. Qu, S. Li, R. Wu, and K. Zheng, "Effect of nitric oxide treatment on storage quality of Glorious oranges," Procedia Engineering, vol. 62, pp. 127-132, 2012.

[15] J.B. Manandhar, G.L. Hartman, and T.C. Wang, "Anthracnose development on pepper fruits inoculated with Colletotrichum gloeosporioides," J. Plant Disease, vol. 79, pp. 380-383, 1995

[16] B.S-B. Marianne, S.P. Anne, A.B-V. Sandra, S.M. Leo, J.M. Peter, E. van den, and J.C.C. Ben, "Only specific tobacco (Nicotiana tabacum) chitinase and $\beta$-1,3-Glucanases exhibit antifungal activity," J. Plant Physiology, vol. 101, pp. 857-863, 1993. 
[17] X. Meng, B. Li, J. Liu, and S. Tian, “ Physiological responses and quality attributes of table grape fruit to chitosan preharvest spray and postharvest coating during storage," J. Food Chemistry, vol. 106, pp. 501-508, 2008.

[18] L.V. Modolo, F.Q. Cunha, R.B. Maircia, and I. Salgado, "Nitric oxide synthase mediated phytoalexin accumulation in soybean cotyledons in response to the Diaporthe phaseolorum f. sp. Meridionallis elicitor," J. Plant Physiology, vol. 130, pp. 1288-1297, 2002

[19] H. Qian, W. Chen, J. Li, J. Wang, Z. Zhou, W. Liu, and Z. Fu, "The effect of exogenous nitric oxide on alleviating herbicide damage in Cholrella vugaris," J. Aquatic Toxicology, vol. 92, pp. 250-257, 2009.

[20] I.I. Salles, J.W. Blount, R.A. Dixon, and K. Schubert, "Phytoalexin induction and beta-1,3-glucanase activities in Colletotrichum trifolii infected leaves of alfalfa (Medicago sativa L.)," J. Physiological and Molecular Plant Pathology, vol. 61(2), pp. 89-101, 2002.

[21] P.N. Sharma, M. Kaur, O.P. Sharma, P. Sharma, and A. Pathania, "Morphological, pathological and molecular variability in Colletotrichum capsici, the cause of fruit rot of chillies in the subtropical region of north-western India," J. Phytopathology, vol. 153(4), pp. 232-237, 2005.

[22] D. Sharp, K.S. Braithwaite, J.A.R. Irwin, and J.M. Manners, "Biochemical and cytochemical responses of Stylosanthes guianensis to infection by Colletotrichum gloeosporioides: association of callose deposition with resistance," Canadian Journal of Botany, vol. 68, pp. 505-511, 1990.

[23] S.G. Shoutherton, and B.J. Deverall, "Changes in phenylalanine ammonia-lyase and peroxidase activites in wheat cultivars expressing resistance to the leaf-rust fungus," J. Plant Pathology, vol. 39(2), pp. 223-230, 1990.

[24] J.H. Simmonds, "A study of the species of Colletotrichum causing ripe fruit rots in Queensland," Queensland J. Agriculture and Animal Science, vol. 22, pp. 437-459, 1965.

[25] Y. Tada, T. Mori, T. Shinogi, N. Yao, S. Takahashi, and S. Betsuyaku, "Nitric oxide and reactive oxygen species do not elicit hypersensitive cell death but induce apoptosis in the adjacent cells during the defense response of oat," Molecular Plant-Microbe Interactions J., vol. 17, pp. 245-253, 2004.

[26] L.C. van Loon, and E.A. van Strien, "The families of pathogenesis-related proteins, their activities and comparative analysis of PR-1 type proteins," J. Physiology and Molecular Biology of Plants, vol. 55, pp. 85-97, 1999.
[27] L.C. van Loon, M. Rep, and C.M.J. Pietersen, "Significance of inducible defense-related proteins in infected plants," Annual Review of Phytopathology, vol. 44, pp. 135-162, 2006.

[28] P. Vander, M.V. Kjell, A. Domard, N.E. El-Gueddari, and B.M Moerschbacher, "Comparison of the ability of partially Nacetylated chitosans and oligosaccharides to elicit resistance in wheat leaves," J. Plant Physiology, vol. 118, pp. 1353-1359, 1998.

[29] C.Y. Wang, "Physiological and biochemical responses of plants to chilling stress," American Society for Horticultural Science, vol. 17(2), pp. 173-186, 1982.

[30] J. Yin, S. Bai, F. Wu, G. Lu, and H. Yang, "Effect of nitric oxide on the activity of phenylalanine ammonia-lyase and antioxidative response in sweet potato root in relation to wound-healing," J. Postharvest Biology and Technology, vol. 74, pp. 125-131, 2012.

[31] Y.J. Yuan, C. Li, Z.D. Hu, J.C. Wu, and A.P. Zeng, "Fungal elicitor induces cell apoptosis in suspension cultures of Taxus chinensis var mairei for toxol production," Process Biochemistry J., vol. 38, pp. 193-198, 2002.

[32] S.S. Zaharah, and Z. Singh, "Mode of action of nitric oxide in inhibiting ethylene biosynthesis and fruit softening during ripening and cool storage of 'Kensington Pride' mango," J. Postharvest Biology and Technology, vol. 62, pp. 127-132, 2011.

[33] Y.H. Zhang, X.F. Yang, Q. Liu, D.W. Qiu, Y.L. Zhang, H.M. Zeng, J.J. Yuan, and J.J. Mao, "Purification of novel protein elicitor from Botrytis cinerea that induces disease resistance and drought tolerance in plants," J. Microbiological Research, vol. 165, pp. 142-151, 2010.

[34] Y. Zheng, L. Shen, M. Yu, B. Fan, D. Zhao, L. Liu, and J. Sheng, "Nitric oxide synthase as a postharvest response in pathogen resistance of tomato fruit," J. Postharvest Biology and Technology, vol. 60, pp. 38-46, 2011.

[35] S.H. Zhu, M.C. Liu, and J. Zhou, "Inhibition by nitric oxide of ethylene biosynthesis and lipoxygenase activity in peach fruit during storage," J. Postharvest Biology and Technology, vol. 42, pp. 41-48, 2006.

[36] S.H. Zhu, J. Zhou, H. R. Shu, and L.L. Wang, "Effects of nitric oxide (NO) on ripening and senescence of strawberry," J. Agricultural Science China, vol. 38, pp. 1418-1424, 2005.

[37] M. Zucker, "Light and enzymes," Annual Review of Plant Physiology, vol. 23, pp. 133-156, 1972. 